\title{
Studies on growth and survival of stone grafts as influenced by age of seedling rootstock in mango (Mangifera indica L.) cv. Amrapali
}

\author{
Niranjan Singh ${ }^{1}$, S. M. Tripathy ${ }^{2}$ and Vikas Ghumare ${ }^{3 *}$ \\ ${ }^{1}$ Department of Fruit Science, College of Horticulture, University of Horticulture and Forestry, Nauni, Solan \\ (Himachal Pradesh), INDIA \\ ${ }^{2}$ Department of Horticulture, Chandra Shekhar Azad University of Agriculture and Technology, Kanpur (Uttar Pradesh), \\ INDIA \\ 3*Department of Agricultural and Food Engineering, Indian Institute of Technology, Kharagpur-721302 (West Bengal), \\ INDIA \\ *Corresponding author. E-mail: agrihortiscience@gmail.com
}

Received: July 21, 2014; Revised received: October 5, 2014; Accepted: November 29, 2014

\begin{abstract}
Stionic relationship is an important factor for successful graft production. Stone grafting was performed by cleft method in the month of July-August on seedling rootstocks (Mango seedlings) of on four age groups i.e. 5 days, 10 days, 15 days and 20 days using Amrapali as scion stock at Kanpur district of Uttar Pradesh. The objective was to analyze age effect of mango seedling rootstock after stone grafting of cultivar Amarpali. Statistically data was analyzed with randomized block design replicating single interval five times. The height $(24.4 \mathrm{~cm})$ and sprouting percentage $(83 \%)$ of scion, girth of rootstock and scion $(6.3 \mathrm{~mm})$ was significantly higher on grafts made on 10 days old rootstocks and minimum-sprouting percentage was recorded with 20 days old rootstocks. In vegetative parameters length $(17.12 \mathrm{~cm})$ and width $(4.80 \mathrm{~cm})$ of leaf was recorded maximum on 10 days old and minimum on 5 days old rootstock. The higher survival percentage was exhibited by 5 days and 10 days old rootstock, which shows suitability for this technique. It was revealed that stone/epicotyl grafting performed better in terms of growth and survival when rootstocks up to 10 days old were used for grafting.
\end{abstract}

Keywords: Mango, Rootstock, Sprout, Stone grafting, Survival

\section{INTRODUCTION}

Mango (Mangifera indica L.) is the best known of the family 'Anacardiaceae' having excellent taste, flavor and aroma. It is regarded as the king of the fruits and the national fruit of India. It is extensively cultivated on 2500000 ha area with a national production and productivity of $18002000 \mathrm{MT}$ and $7.2 \mathrm{MT} / \mathrm{ha}$, respectively. In India Uttar Pradesh leads in productivity which is almost double than national productivity i.e. $16 \mathrm{MT} / \mathrm{ha}$. The area and production is highest in Andra Pradesh, which is 489600 ha, and 4406920 MT, respectively (NHB, 2013).

The major concern for increasing area under mango cultivation is non-availability of quality planting material of desired variety in required number is one of the most important bottlenecks in increasing area under mango cultivation. However, stionic relationship is an important factor for successful graft production. Though inarching and veneer grafting methods are commonly followed but the stone grafting being easy, cheap and one of the rapid method to produce high quality and quantity planting material in less time and area. It is becoming popular in the states like Maharashtra, Karnataka and Kerala (Majumdar, 1989).
Among different factors, which affect the growth and survival of grafts is the age of rootstocks is important with success and survival of grafts (Ratan et al., 1987). However, moderate temperature and high relative humidity are major factors related to success of grafts (Litz, 1997). Therefore, efforts have been made to take up seedling rootstocks of different age groups to see their impact on various parameters of stone grafts including their survival, which was the ultimate outcome of the technique through our work on Amrapali cultivar as it gave highest success per cent and overall performance of stone grafting operation.

\section{MATERIALS AND METHODS}

The experiment was conducted in the Horticultural Garden of Chandra Shekhar Azad University of Agriculture and Technology, Kanpur during the year 2011-2012.

Selection of rootstock: Healthy and uniform germinating seedlings were selected from the nursery at the age of 5,10,15 and 20 days to be used as rootstock. Freshly extracted healthy stones were stored in poly bags for frequent sowing at 4 days interval so that the availability of the desirable seedling stocks 
could be made at the time of grafting.

Selection of scion: Properly tagged and marked healthy 4-5 month old scions of Cv. Amrapali were selected in the moth of Feb.-Mar.

Time of grafting : The grafting was performed during the last week of July and first week of August of 2011.

Technique of operation: The stone grafting was performed by the cleft method of grafting. In general, the technique was more or less similar as suggested by Bhan et al., (1969). The stock was decapitated at $5 \mathrm{~cm}$ height with a length of vertical cut being kept at $3 \mathrm{~cm}$ to receive the scion.

Nursery practices: Raised beds of $1 \times 1 \mathrm{~m}$ were prepared for sowing the freshly extracted healthy uniform stones to ensure the availability of seedlings to be used as rootstocks. The sown stones were covered with fine leaf mold and dry leaves to facilitate germination.

The uniform cultural practices with regard to watering, hoeing, weeding, manuring and plant protection measures were adopted. Total number of sprouted stone grafts was counted and the percentage of sprouting grafts was calculated on the basis of total number of grafts per treatment. The diameter of the rootstock of the graft was recorded in $\mathrm{mm}$ with the help of vernier calipers after 30 days and 120 days of grafting. The diameter of the scion of the graft was recorded in $\mathrm{mm}$ with the help of vernier calipers after 30 days and 120 days of grafting. As maximum mortality in the stone occurs during the initial months of stone grafting in North Indian conditions. For calculating survival percentage data on the grafts surviving after 120 days of grafting were considered. The height of the graft was recorded in $\mathrm{cm}$ after 30 days and 120 days of grafting. The number of leaves/graft was recorded after 120 days of grafting. Sprout length of the graft was recorded in $\mathrm{cm}$ after 120 days of grafting. Length of the leaves was recorded in $\mathrm{cm}$ after 120 days of grafting. Width of the leaves was recorded in $\mathrm{cm}$ after 120 days of grafting. Data were averaged over the two growing seasons and then subjected to statistical analysis with the SAS (Ramon et al., 2002).

\section{RESULTS AND DISCUSSION}

Sprouting percentage: The impact of different age groups rootstock on sprouting percentage of grafts were significantly higher on 10 days old rootstock after 10 days and 20 days of grafting as compared to other age groups used (Table 1). The lower sprouting percentage was recorded under 20 days old rootstock after 10 days and 20 days of grafting.

Rootstock and scion girth: After 30 days and 120 days of grafting 10 days old rootstocks exhibited significantly highest girth of graft than the rest combinations (Table 1). The lowest was found on 20 days old rootstock.

Significantly higher scion girth was recorded on 10 days old rootstock as compared to 20 days old after 30

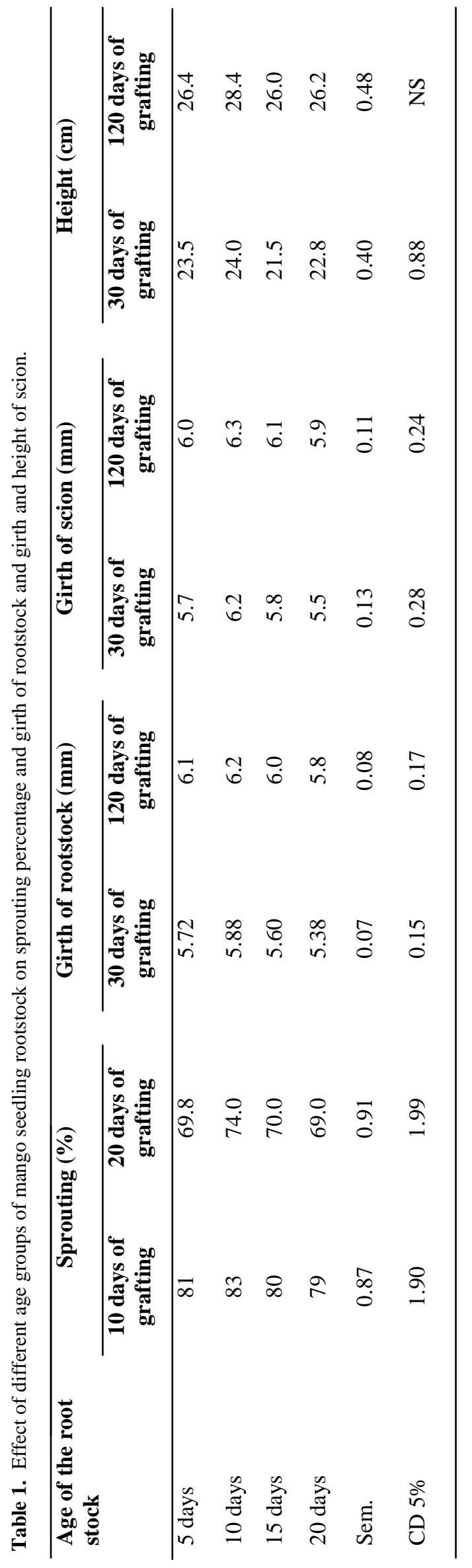


Table 2. Effect of four age groups of mango seedling rootstock on vegetative growth parameters and survival percentage of grafts.

\begin{tabular}{lccccc}
\hline $\begin{array}{l}\text { Age of the root } \\
\text { stock }\end{array}$ & $\begin{array}{c}\text { Sprout length } \\
(\mathbf{c m})\end{array}$ & $\begin{array}{c}\text { Number of } \\
\text { leaves }\end{array}$ & $\begin{array}{c}\text { Length of } \\
\text { leaf }(\mathbf{c m})\end{array}$ & $\begin{array}{c}\text { Width of leaf } \\
(\mathbf{c m})\end{array}$ & $\begin{array}{c}\text { Survival } \\
\text { percentage }\end{array}$ \\
\cline { 2 - 6 } & $\begin{array}{c}\text { 120 Days of } \\
\text { grafting }\end{array}$ & $\begin{array}{c}\text { 120 Days of } \\
\text { grafting }\end{array}$ & $\begin{array}{c}\mathbf{1 2 0} \text { Days of } \\
\text { grafting }\end{array}$ & $\begin{array}{c}\mathbf{1 2 0} \text { Days of } \\
\text { grafting }\end{array}$ & $\begin{array}{c}\text { 120 Days of } \\
\text { grafting }\end{array}$ \\
\hline 5 days & 5.5 & 7.6 & 16.14 & 4.18 & 53.4 \\
10 days & 6.0 & 10.0 & 17.12 & 4.80 & 49.2 \\
15 days & 5.4 & 8.8 & 16.36 & 4.54 & 45.0 \\
20 days & 5.3 & 8.2 & 16.10 & 4.38 & 40.0 \\
Sem. & 0.19 & 0.53 & 0.29 & 0.18 & 1.6 \\
CD5\% & 0.43 & 1.15 & 0.64 & 0.40 & 3.4 \\
\hline
\end{tabular}

and 120 days of grafting (Table 1). Similarly, data recorded on graft height after 30 days and 120 days of grafting revealed that graft with 10 days old rootstock exhibited maximum increase in height than the restage group rootstocks (Table 1). However, minimum was recorded with 15 days old rootstock.

Sprout length: At final stage graft with 10 days old rootstock recorded significantly higher sprout length (Table 2) as compared to the 5 days, 15 days and 20 days old rootstocks, which did not differ significantly among themselves. The sprout length of scion after 120 days was significantly lower in stock scion combination with 20 days old rootstock.

Vegetative growth: The influence of age of rootstock on number of leaves/graft (Table 2) using 10 days old rootstock produced significantly higher number of leaves per graft as compared to all other age groups. While, lower numbers of leaves were recorded on grafts on 5 days old rootstock. Among different combinations the length and width of leaf was higher in grafts using 10 days and minimum in 5 days, 15 days and 20 days old rootstocks for grafting. Jha and Brahmachari (2002) reported similar results with respect to our study. They found that the four month old scions and 6 days old rootstocks, respectively, required the shortest time for sprouting and recorded the highest values after six months for length of scion, diameter of scion, number of leaves per graft, total leaf area, graft survival and grafting success. Ram et al., (2012) also recorded maximum number of leaves on Amrapali scion grafted plants, 30 and 60 days after grafting.

Survival percentage: Among different graft combinations those with 5 days old rootstocks recorded significantly higher survival percentage (Table 2) than the remaining graft combinations after 120 days of grafting. All the combinations, exhibited significant variation $(\mathrm{P}=0.05)$ in survival percentage with each other. There was negative relationship between age of rootstock and survival percentage of graft. Dhunga et al. (1989) also reported negative relationship between age of rootstocks and of stone grafts. Rootstock age differed with respect to graft success in veneer Similar findings were given by
Gagandeep and Malhi (2006) that the highest survival percentage was observed with 7 days old rootstock, the survival rate decreased when the age of the stock increased to 15 days. Further, Lal (1993) also reported the effects of rootstock age differences in stone grafts of mango with regard to sprouting percentage, graft quality, number of leaves on graft and survival per cent. He noted superior success and survival in 5 days and 10 days old rootstock than 15 days and 20 days old rootstock.

The study showed that rootstock age beyond 10 days i.e. 15 days and 20 days, adversely affected both sprouting and survival per cent, quality in terms of height, girth of graft stock and size, number of leaves of scion. Patil et al., (1984) recited that six days old rootstock and five days defoliation before grafting operation was optimum for quick sprouting and greater success of mango grafts. Brahmachari et al., (1999) reported that as the age of rootstock increases the success of grafting was reduced considerably.

\section{Conclusion}

Stone/Epicotyl grafting performed better in terms of growth and survival when rootstocks up to 10 days old were used for grafting. The performance of grafts was adversely affected with the use of 15 and 20 days old mango seedling rootstock. From our study it was confirmed that the age of rootstock has definite effect on survival of the grafted plants. The five days old rootstock gave highest survival percentage of $\mathrm{cv}$. Amrapali mango plants and as age of the plants increased the survival percentage was decreased simultaneously.

\section{ACKNOWLEDGEMENTS}

Authors are highly thankful to the facilities and funds provided by Chandra Shekhar Azad University of Agriculture and Technology, Kanpur (Uttar Pradesh).

\section{REFERENCES}

Bhan, K.C., Sammaddar, H.N. and Yadav, P.S. (1969). Clip budding and stone grafting of mangos in India. Tropical Agriculture, 45: 247-53.

Brahmachari, V.S., Singh, M.P. and Bishwas, R.C. (1999). 
Effect of period of defoliation of scion and age of rootstock on success of epicotyl grafting in mango (Mangifera indica L.) cv Amrapali. Orissa Journal of Horticulture, 27(2):1-4.

Dhunga, D.B., Aravindakshan, M. and Gopi, Kumar, K. (1989). Standardization of stone grafting in mango. Acta Horticulture, 231: 170-174.

Gagandeep, Kaur and Malhi, C.S. (2006). Effect of age of rootstock and growing medium on the success of epicotyl grafting in mango. Indian Journal of Horticulture, 63 (3): 244-247.

Jha, U.N. and Brahmachari, V.S. (2002). Success in stone grafting of mango asinfluenced by the defoliation of scion and age of rootstocks and scion shoots. Horticultural Journal, 15 (1): 9-17.

Lal, B. (1993). Standardization of stone grafting in mango (Mangifera indica L.). Ph.D. Thesis, C.S.A.U., Kanpur.

Majumdar, P.K. (1989). Recent advances in propagation and rootstocks research in mango world situation. Acta Horticulture, 231: 157-161.

NHB (2013). Indian Horticultural Database. National Horticultural Board, MOA, GOI. pp 96.

Ram, R.B., Kumar, D., Priyamvada, Sonkar, Rubee, Lata and Meena, M.L. (2012). Standardization of stone grafting in some mango cultivars under Lucknow conditions. Hort Flora Research Spectrum, 1(2): 165-167.

Litz, R.A. (1997). Propagation. In: The Mango- Botany, Production and Uses. (ed.). CAB International. pp. 363-400.

Patil, J.G., Worko, D.C., Patil, V.K. and Gunjakar, S.K. (1984). Studies on the Epicotyl grafting in Mango. Indian Journal of Horticulture, 41 (1-2): 69-72.

Ramon, Littell, C., Walter, Stroup, W. and Roudlf, Freund, J. (2002). SAS for linear models, fourth edition.

Ratan, J., Aravindakshan, M. and Gopi, Kumar. (1987). Studies on stone grafting in mango. South Indian Horticulture, 35 (3): 192-199. 